\title{
Influence of intertidal Manila clam Venerupis philippinarum aquaculture on biogeochemical fluxes
}

\author{
Marie-France Lavoie ${ }^{1}$, Christopher W. McKindsey ${ }^{2, *}{ }^{,}$Christopher M. Pearce $^{3}$, \\ Philippe Archambault ${ }^{1}$
}
${ }^{1}$ Laboratoire d'écologie benthique, Institut des sciences de la mer, Université du Québec à Rimouski, 310 Allée des Ursulines CP 3300, Rimouski, Québec G5L 3A1, Canada
${ }^{2}$ Demersal and Benthic Sciences Division, Institut Maurice-Lamontagne, Fisheries and Oceans Canada, PO Box 1000, Mont Joli, Québec G5H 3Z4, Canada
${ }^{3}$ Marine Ecosystems and Aquaculture Division, Pacific Biological Station, Fisheries and Oceans Canada, 3190 Hammond Bay Road, Nanaimo, British Columbia V9T 6N7, Canada

\begin{abstract}
Bivalve aquaculture introduces high densities of farmed organisms to the natural environment with potential consequences on a number of ecosystem processes, including modification of nutrient fluxes (e.g. $\mathrm{NH}_{4}, \mathrm{NO}_{\mathrm{X}}, \mathrm{PO}_{4}$, and $\mathrm{Si}(\mathrm{OH})_{4}$ ) and benthic respiration, and may impact benthic communities. Infaunal clam culture may influence the environment due to the clams themselves [their metabolic processes (e.g. feeding, respiration), production of faeces/ pseudofaeces, and/or trapping of organic matter], the farm structures, or the fouling on these structures. This study examined how farmed Manila clams Venerupis philippinarum, the nets placed on beaches to protect them from predators, and the fouling organisms growing on these nets modify nutrient fluxes, benthic respiration, and benthic community structure in coastal British Columbia, Canada. In 2012, a manipulative experiment involving sixty $2.25 \mathrm{~m}^{2}$ plots and 6 treatments was conducted on an intertidal farmed beach to evaluate the effect of clams (presence/ absence) and net status (fouled, cleaned, and absent). Percentage organic matter in the first centimetre of sediment was significantly greater with the presence of clams than without. The abundance and taxonomic richness of organisms in sediments were significantly affected by net status. Nutrient fluxes and oxygen consumption increased significantly with the presence of clams, the latter also increasing with the presence of nets and fouling on nets (incubated under dark conditions). These results show that farmed clams and the structures used to culture them influence several environmental parameters, and provide a better understanding of the role of these factors in modulating the benthic environment.
\end{abstract}

KEY WORDS: Aquaculture · Manila clams · Venerupis philippinarum • Biogeochemical fluxes · Anti-predator nets $\cdot$ Benthic communities

\section{INTRODUCTION}

Aquaculture is expanding worldwide due to an increased demand for seafood by a growing human population, a demand that cannot be met by existing wild fisheries, most of which have reached a plateau or are in decline (FAO 2014). According to the Food and Agriculture Organization (FAO 2014), the proportion of total world aquaculture production (by

\footnotetext{
*Corresponding author: chris.mckindsey@dfo-mpo.gc.ca
}

mass) of animals in 2012 was $57.9 \%$ for inland fish, $22.8 \%$ for molluscs, $9.7 \%$ for crustaceans, $8.3 \%$ for marine fish, and $1.3 \%$ for other aquatic animals. Since 2008, clams and cockles are the group of bivalves with the greatest farmed production worldwide-nearly 5 million tonnes in 2011. In Europe and North America, $40 \%$ of the total production of molluscs is represented by Manila clams Venerupis philippinarum and Pacific oysters Crassostrea gigas

(C) Fisheries and Oceans Canada and M.-F. Lavoie, P. Archambault 2016. Open Access under Creative Commons by Attribution Licence. Use, distribution and reproduction are unrestricted. Authors and original publication must be credited.

Publisher: Inter-Research · www.int-res.com 
(FAO Fisheries and Aquaculture Department 2013). British Columbia, Canada, produces greater than half of the farmed fishes and bivalves in the country (Fisheries and Oceans Canada 2013), with the most farmed bivalve species being the Manila clam (BC Shellfish Grower's Association 2014).

Bivalve culture is commonly considered to have less impact on the environment than fish farming, as filter-feeding bivalves do not require external inputs of feed (Naylor et al. 2000, Newell 2004, Dumbauld et al. 2009). Nevertheless, suspension-feeding bivalves play important functional roles in aquatic ecosystems, since they may affect various physical and biological processes in both the water column and the benthic environment (Newell 2004, Nizzoli et al. 2006a). Numerous studies have described the influence of bivalve culture on various components of the environment, including nutrient cycling (Doering et al. 1987, Baudinet et al. 1990, Nizzoli et al. 2006a,b, Richard et al. 2006, 2007b, Thouzeau et al. 2007), localized organic loading (Mattsson \& Lindén 1983, Weise et al. 2009), benthic macrofaunal communities (Kaiser et al. 1996, Spencer et al. 1996, 1997, Jie et al. 2001, Callier et al. 2008), and seston (Newell 2004, Guyondet et al. 2013). High densities of infaunal filter-feeding bivalves may influence benthic environments either directly, through their metabolic activity (e.g. oxygen consumption and ammonium production) and feeding, or indirectly, by modifying biogeochemical processes at the water-sediment interface (Doering et al. 1987, Baudinet et al. 1990, Magni et al. 2000). Only a portion of the food captured by bivalves is ingested and used for respiration, growth, and reproduction; the other fraction is released postdigestion as faeces or, if rejected prior to ingestion, as consolidated particles, termed pseudofaeces (Navarro \& Thompson 1997). Such uningested particles consist of plankton and suspended matter which are either too large to be ingested by the bivalve or not of sufficient quality and rejected. Pseudofaeces and faeces are collectively known as biodeposits. Biodeposition by cultured bivalves may lead to accumulation of organic matter within farm areas (Jie et al. 2001), and related high concentrations of benthic organic matter may induce mineralization processes and stimulate both aerobic and anaerobic metabolism and nutrient recycling (Kaspar et al. 1985, Baudinet et al. 1990). Benthic processes are more complicated when farmed bivalves are infaunal species (as compared to farming bivalves in suspended and off-bottom culture), such as Manila clams, because they not only increase biodeposition locally but also live within the sediments (Bartoli et al. 2001), with both factors poten- tially influencing benthic processes. Nizzoli et al. (2006b) described 3 ways by which infaunal clams influence the benthic environment: biodeposition of organic matter, bioturbation (whereby their activities allow for increased oxygen exchange), and bioirrigation.

Potential impacts on the environment from infaunal bivalve culture may result from more than just the animals themselves. Dumbauld et al. (2009) suggested that the physical structures used in grow-out and the pulse disturbances caused by harvesting and biofouling-removal activities may also influence benthic environments. A number of studies and reviews (e.g. Ross et al. 2004, McKindsey et al. 2011) have highlighted the importance of physical structures (nets, cages, tubes, etc.) used in bivalve culture, since they provide novel substrata for the establishment of various invertebrate, algal, and microbial communities. In Manila clam culture, nets may be placed directly on the bottom over clams to prevent predators - such as benthic fish, seastars, and birds - from consuming the farmed bivalves (Spencer et al. 1992, Jamieson et al. 2001). In Baynes Sound (British Columbia, Canada), bivalves account for $>90 \%$ of the total dry mass of shell fragments in the faeces of 2 sea-duck species (the scoters Melanitta perspicilata and M. fusca), Manila clams being one of the important prey items (Lewis et al. 2007). Although large clams are energetically expensive to consume, Lewis et al. (2007) showed that the population of 25 to $45 \mathrm{~mm}$ clams declined by $30 \%$ after ducks had fed extensively in the study area. Netting is thus considered an important tool to reduce the predation impacting Manila clam production. Anti-predator nets, however, may increase the concentration of organic matter on the sea floor by creating a barrier to water movement (Spencer et al. 1996, 1997, Bendell-Young 2006). They may also influence benthic macrofaunal communities. For example, Spencer et al. (1997) demonstrated that there was a greater abundance of deposit feeders under nets used in Manila clam culture than in reference areas. Antipredator nets also allow the establishment of microalgae and macroalgae, which may serve as habitat for other organisms (Powers et al. 2007) or assimilate the nutrients released by the clams (Castaldelli et al. 2003). The fouling organisms typically found on Manila clam anti-predator nets include mussels, barnacles, tunicates, tube worms, bryozoans, hydroids, and encrusting sponges (BC Shellfish Grower's Association 2014). In Manila clam culture in Canada, nets are installed for the entire culture period ( 3 to $4 \mathrm{yr}$ ) and are manually washed only when required (often 
in spring or autumn), i.e. when fouling reduces water movement and food renewal to clams (Jamieson et al. 2001). There are no regulations governing the total area of the intertidal region that may be covered by nets (Jamieson et al. 2001), which may represent a considerable proportion of the foreshore (Carswell et al. 2006, Bendell \& Wan 2011). Given the potential impacts of anti-predator netting on both infaunal and epifaunal community structure and water exchange, it seems logical that both nutrient fluxes and benthic respiration may also be affected, directly and/or indirectly, by netting.

The present study used an in situ manipulative field experiment to evaluate how biological (Manila clams and biofouling on anti-predator nets) and physical (anti-predator nets) factors related to Manila clam culture influence organic loading, benthic communities, oxygen consumption, and biogeochemical fluxes (change in nutrient concentrations over time). We hypothesized that the presence of Manila clams, anti-predator nets, and fouling on the nets increases organic loading, the number and richness of associated organisms, oxygen consumption, and nutrient fluxes.

\section{MATERIALS AND METHODS}

\section{Study site}

The study was conducted in Fanny Bay $\left(49^{\circ} 30.652^{\prime} \mathrm{N}, 124^{\circ} 49.899^{\prime} \mathrm{W}\right)$, Baynes Sound, on Vancouver Island, British Columbia, Canada (Fig. 1) in summer 2012. Baynes Sound is bordered to the west by Vancouver Island and to the east by Denman
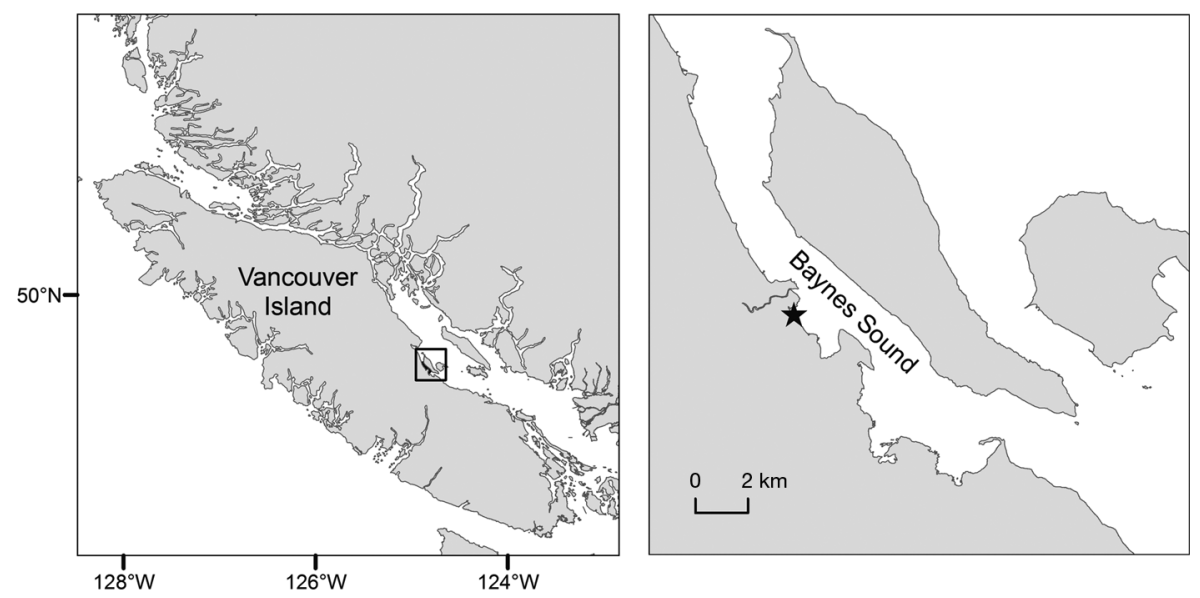

Fig. 1. Location of study site ( $\star$ ) in Fanny Bay on Vancouver Island, British Columbia, Canada
Island and is largely characterized by protected bays, open foreshores, tidal estuaries, inshore marshes, and adjacent forests (Jamieson et al. 2001, British Columbia Ministry of Sustainable Resource Management 2002, Carswell et al. 2006). The physical oceanography of the sound is largely controlled by tides, currents, and freshwater inputs (further details may be found in Jamieson et al. [2001] and British Columbia Ministry of Sustainable Resource Management [2002]). The area is highly productive and has large rocky and sandy intertidal beaches that make it ideal for clam culture. Baynes Sound is of great importance for the bivalve aquaculture industry in the province, as $>50 \%$ of the total production occurs there (British Columbia Ministry of Sustainable Resource Management 2002).

\section{Experimental design}

The experimental site was within a bivalve aquaculture lease that was not farmed in 2012. A grid $(19.5 \times 51.0 \mathrm{~m})$ with 60 intertidal plots $(5 \times 12$ array, $2.25 \mathrm{~m}^{2}$ plots) was established on the beach above the low tide level, with the long edge of the grid parallel to the low tideline. Individual plots were separated by $3 \mathrm{~m}$ to limit their influence on neighbouring ones. The sediment in each plot was excavated to a depth of about $10 \mathrm{~cm}$, sieved $(1 \times 1 \mathrm{~cm}$ mesh size $)$ to remove wild Manila clams Venerupis philippinarum, and placed back into the plots between June 20 and July 6. Each plot was randomly assigned to 1 of 6 treatments $(\mathrm{n}=10)$, with 2 plots per treatment randomly established per row, in an attempt to account for variation in submersion times among rows. In fact, tidal incursion started from the southeast corner of the grid, and the entire grid was typically inundated within about $40 \mathrm{~min}$, and so this factor was excluded from subsequent analyses. It took 2 wk (July 9 through 21) to install all the plots with associated treatments, and these were done in a random order. The treatments evaluated the influence of 2 factors: clam presence/absence (Clam - 2 levels: with and without clams) and net status (Net - 3 levels: fouled nets, cleaned nets, and without nets) in a crossed design that gave 6 treatments: (1) Manila 
clams with fouled nets (M-F), (2) Manila clams with clean nets (M-C), (3) Manila clams without nets (MW), (4) without Manila clams with fouled nets (W-F), (5) without Manila clams with clean nets (W-C), and (6) without Manila clams and without nets (W-W). The $\mathrm{W}-\mathrm{W}$ treatment was installed as a procedural control treatment. Plots with clams were seeded with 675, 3 to $4 \mathrm{~cm}$ shell-length (commercial size) Manila clams (300 ind. $\mathrm{m}^{-2}$, the typical commercial density). These were partially pressed into the substrate by hand to ensure that they would not be displaced by currents from the incoming tide. At the time of sampling, mean Manila clam densities, as measured from sampled cores, were: $398 \mathrm{~m}^{-2}$ (M-W), $438 \mathrm{~m}^{-2}$ (M-C), and $470 \mathrm{~m}^{-2}$ (M-F) in plots seeded with clams and $8 \mathrm{~m}^{-2}$ (W-C and W-W) and $48 \mathrm{~m}^{-2}$ (W-F) in unseeded plots. Fouled netting being used at a nearby aquaculture site was collected, cut into $2.25 \mathrm{~m}^{2}$ pieces, and cleaned by hand if necessary (i.e. for $\mathrm{C}$ treatments). Rebar 'staples' used in commercial operations were used to maintain the nets in position. Plots and clams were allowed to stabilize for about 1 mo before sampling.

Sampling was done at high tide between August 4 and 22 by SCUBA divers. Each plot was sampled only once and only 4 to 5 plots could be sampled each day. The order of plot sampling was determined randomly based on the timing of plot set-up to ensure the longest period for plots to stabilize and only 8 of the 10 plots $(n=8)$ per treatment were sampled due to logistical constraints. For each plot sampled, a benthic chamber was installed in the central portion of the plot and left in place for a treatment-specific, pre-determined time to measure biogeochemical fluxes and oxygen consumption (respiration). Following an incubation period, sediment cores were collected from random positions within the area over which the benthic chamber was installed to determine sediment organic matter content (\%OM), sediment grain size (granulometry), and assemblage composition of macrofauna (see sampling details in 'Sediment characteristics' and 'Macrofaunal communities' below).

\section{Sediment characteristics}

Sediment characteristics were determined for the upper $2 \mathrm{~cm}$ of sediment cores taken with $60 \mathrm{ml}$ cut-off syringes (inner diameter: $2.7 \mathrm{~cm}$ ). All cores were kept frozen $\left(-20^{\circ} \mathrm{C}\right)$ until analyzed. For each plot, sediment \%OM was evaluated for the surficial first and second centimetres using samples from 3 sediment cores, whereas granulometry was evaluated based on 2 cores. Sediment \%OM was determined as the difference between the mass of samples after drying at $60^{\circ} \mathrm{C}$ for $48 \mathrm{~h}$ and mass after having been ashed for $5 \mathrm{~h}$ at $440^{\circ} \mathrm{C}$ (Byers et al. 1978). Although samples may be pre-treated with a $\mathrm{HCl}$ solution to remove carbonates and thus avoid overestimating \%OM (Byers et al. 1978), ashing at $440^{\circ} \mathrm{C}$ limits destruction of inorganic carbonates that may be present (Schumacher 2002). Samples to evaluate sediment grain size and sediment composition (sediment type: \%gravel, \%sand, \%silt, and \%clay) were initially prepared with a dispersal agent (Calgon solution) and then analyzed with a Beckman Coulter LS13200, ALM laser-diffraction, particle-size analyzer (McCave et al. 1986).

\section{Macrofaunal communities}

In plots with nets, the net under the benthic chamber (diameter: $\sim 53 \mathrm{~cm}$ ) was removed by cutting with scissors and kept frozen at $-20^{\circ} \mathrm{C}$ until the associated macrofauna were identified in the laboratory. Macroinfaunal communities were evaluated by collecting 2 circular cores (diameter: $10 \mathrm{~cm}$, depth: $10 \mathrm{~cm}$ ) from each replicate plot. Core contents were sieved on a $1 \mathrm{~mm}$ mesh, and the retained material was preserved in a $4 \%$ buffered formaldehyde solution. Identification was made (by the same person) to the lowest taxonomic level possible (usually species). Total abundance per taxa was recorded for each plot for both sediment and net communities.

\section{Biogeochemical fluxes}

Biogeochemical fluxes were calculated at the water-sediment interface using in situ benthic chambers $(60 \mathrm{~cm}$ diameter hemispheres atop a $20 \mathrm{~cm}$ high base) modified from Richard et al. (2007b) and Robert et al. (2013) to allow sampling with the presence of nets and large infaunal bivalves. To this end, the lower edges of chambers were of soft foam that took the form of the seafloor, and weights were added to chambers to provide downward pressure to maintain them in place and provide a tight fit to the seafloor. Chambers were opaque, to ensure that photosynthetic activity did not affect biogeochemical fluxes and respiration rates, and made use of a submersible pump (flow rate: $21 \mathrm{~min}^{-1}$, verified by a flow meter) to create a strong enough current within them to avoid water stratification but weak enough to avoid resus- 
pension of sediments (Thouzeau et al. 2007). An inline, multi-parameter probe (YSI 6600, YSI Incorporated) was used to monitor various basic parameters including temperature $\left({ }^{\circ} \mathrm{C}, \pm 0.01\right)$, salinity $( \pm 0.01)$, and oxygen levels $\left(\mathrm{mg} \mathrm{O}_{2} \mathrm{l}^{-1}, \pm 0.01\right)$ throughout the incubations. Incubations were initiated at least 30 min following inundation to avoid sudden pulses of nutrients from sediment pore water that had accumulated during low tide, as has been described by Cabrita et al. (1999).

The 6 treatments were incubated for different periods of time (M-F and M-C: $1 \mathrm{~h} 40$ min; M-W: $2 \mathrm{~h}$ 40 min; W-F and W-C: $3 \mathrm{~h}$, and W-W: $6 \mathrm{~h}$ ) to ensure that oxygen levels within chambers installed over treatment plots did not decrease to $<80 \%$ of initial conditions, below which fauna may display stress responses that could influence fluxes (Mazouni et al. 1998). These time periods were determined on replicate experimental plots that were not selected for complete sampling prior to the experiment. Water from each chamber was sampled at 5 equally spaced times throughout the incubations (with $T_{0}$ being immediately after setting up a chamber and $T_{4}$ at the end of the incubation period). At each time, a syringe was inserted into a port at the top of a benthic chamber and one $60 \mathrm{ml}$ water sample was taken from near the centre of the chamber (after having flushed the syringe with water from the chamber), the sampled water being replaced by ambient water through an adjacent port. This volume of ambient water was negligible compared to the volume of the chamber (80.97 1) and was not included in the calculation of nutrient fluxes. Water samples were filtered on $0.8 \mu \mathrm{m} \mathrm{GF} / \mathrm{F}$ syringe filters to remove larger particles, with three $4 \mathrm{ml}$ sub-samples being frozen $\left(-20^{\circ} \mathrm{C}\right)$ in cryovials for subsequent analyses for nitrite $\left(\mathrm{NO}_{2}\right)$, nitrate $\left(\mathrm{NO}_{3}\right)$, phosphate $\left(\mathrm{PO}_{4}\right)$, and silicate $\left(\mathrm{Si}(\mathrm{OH})_{4}\right)$. Water was also taken from the same syringe to measure ammonium levels. Ammonium measurements were taken immediately after sampling using a 10 AU Turner Designs fluorometer utilizing the OPA (orthophtaldialdehyde) method from Holmes et al. (1999) (Protocol B).

\section{Statistical analyses}

Variation among treatments for sediment and community characteristics was evaluated with permutational analysis of variance (PERMANOVA, with 9999 permutations) using PRIMER 6 (v. 6.1.12) and PERMANOVA+ (v. 1.0.2), as data transformations were unable to constrain the data to meet the assump- tions of ANOVA. Similarity matrices used for PERMANOVAs were constructed based on Euclidean distances for univariate measures (grain size, \%OM in the surficial first and second centimetres, macrofaunal abundance, and richness) and on Bray-Curtis similarity for multivariate metrics (sediment and multivariate community structure). Analyses included 3 factors: Clam (2 fixed levels: with and without), Net status (3 fixed levels: fouled, cleaned, and without), and Plot (nested in Clam $\times$ Net). Differences among treatments were determined using a posteriori pairwise comparisons, also using PERMANOVA. Homogeneity of multivariate dispersion was evaluated using PERMDISP (Anderson et al. 2008) and data transformed (square-root) as necessary. SIMPER analysis was used to identify the macrofaunal species that were most responsible for the dissimilarity among treatments. Multi-dimensional scaling (MDS) was used to show graphically the variation in the benthic assemblages among the treatments.

Variations among treatment means for oxygen consumption and nutrient fluxes were evaluated using 2-way ANOVA with Clam and Net as the main factors. Differences among treatment means of factors that were deemed significant in the ANOVAs were evaluated using a posteriori Tukey multiplecomparison tests. Assumptions of normality and homoscedasticity were verified prior to running ANOVAs, as outlined by Quinn \& Keough (2002). Data were transformed (square-root) prior to analysis, if necessary.

\section{RESULTS}

\section{Sediment characteristics}

Sediment structure (\%gravel, \%sand, \%silt, and $\%$ clay) was not significantly affected by Clam, Net, or the interaction between the 2 factors (Table 1 ). The proportion (mean $\pm \mathrm{SE}$ ) of sediment types in the 6 treatments ranged from $17.77 \pm 4.20$ to $29.28 \pm 4.26 \%$ for gravel, $61.76 \pm 5.62$ to $68.12 \pm 3.16 \%$ for sand, $7.77 \pm 0.88$ to $13.92 \pm 1.30 \%$ for silt, and $0.85 \pm 0.06$ to $1.33 \pm 0.15 \%$ for clay. Sediment grain size did not differ significantly as a function of Clam or Net, but the interaction between these 2 factors was marginally significant (Table 1), grain size being generally larger for treatments with clams when nets were cleaned or absent, but the opposite trend being apparent in treatments without clams (Fig. 2). Grain size (mean $\pm \mathrm{SE}$ ) varied from $445.79 \pm 44.41$ to 832.01 $\pm 81.82 \mu \mathrm{m}$ in the various treatments (Fig. 2). The 
Table 1. Results of PERMANOVAs evaluating the effect of Clam (presence/absence), Net status (fouled, cleaned, or absent), and Plot (replicate plots for same treatment) on various sediment characteristics: sediment types, grain size, and percent organic matter in the 1st and 2nd centimetres of sediment $(\% O M)$. Significant effects $(p<0.05)$ are indicated in bold

\begin{tabular}{|lcccc|}
\hline Source & df & MS & $F$ & $\mathrm{p}$ \\
\hline Sediment types & & & & \\
Clam (C) & 1 & 34.24 & 0.098 & 0.8240 \\
Net $(\mathrm{N})$ & 2 & 142.52 & 0.406 & 0.6901 \\
C $\times$ N & 2 & 689.28 & 1.963 & 0.1456 \\
Plot $(\mathrm{C} \times \mathrm{N})$ & 42 & 351.14 & 2.871 & $\mathbf{0 . 0 0 0 3}$ \\
Error & 48 & 122.33 & & \\
Grain size & & & & \\
Clam $(\mathrm{C})$ & 1 & 768.75 & 0.766 & 0.4112 \\
Net $(\mathrm{N})$ & 2 & 688.81 & 0.687 & 0.5385 \\
C $\times$ N & 2 & 2923.10 & 2.914 & $\mathbf{0 . 0 4 9 7}$ \\
Plot $(\mathrm{C} \times \mathrm{N})$ & 42 & 1003.20 & 2.983 & $\mathbf{0 . 0 0 0 2}$ \\
Error & 48 & 336.31 & & \\
\%OM 1st cm & & & & \\
Clam $(\mathrm{C})$ & 1 & 1438.70 & 6.268 & $\mathbf{0 . 0 1 1 3}$ \\
Net $(\mathrm{N})$ & 2 & 266.28 & 1.125 & 0.3244 \\
C $\times$ N & 2 & 33.43 & 0.141 & 0.9541 \\
Plot $(\mathrm{C} \times \mathrm{N})$ & 42 & 236.73 & 1.953 & $\mathbf{0 . 0 0 1 5}$ \\
Error & 48 & 121.21 & & \\
\%OM 2nd cm & & & & \\
Clam $(\mathrm{C})$ & 1 & 107.12 & 0.276 & 0.8367 \\
Net $(\mathrm{N})$ & 2 & 262.98 & 0.679 & 0.5834 \\
C $\times$ N & 2 & 258.20 & 0.666 & 0.6042 \\
Plot $(\mathrm{C} \times \mathrm{N})$ & 42 & 387.49 & 0.222 & $\mathbf{0 . 0 0 0 1}$ \\
Error & 48 & 174.39 & & \\
\hline
\end{tabular}

$\% \mathrm{OM}$ in the first centimetre of sediments was significantly greater in the treatments with clams than in those without clams, while \%OM in the second centimetre (mean \pm SE) did not vary significantly among treatments for either main factor (Table 1), ranging from $1.55 \pm 0.11$ to $1.88 \pm 0.11 \%$ and $1.47 \pm 0.12$ to $1.76 \pm 0.17 \%$, respectively (Fig. 2). All sediment characteristics differed significantly among Plots within treatments (Table 1).

\section{Macrofaunal communities: sediment}

Data on the abundance of Manila clams in cores were removed from all analyses to evaluate the importance of this factor in modifying other metrics of community structure. Macrofaunal abundance (ind. core ${ }^{-1}$ ) and taxonomic richness (number of taxa core $^{-1}$ ) varied significantly with Net, but not with Clam nor with the interaction between the 2 factors, such that both metrics were greatest for fouled net treatments and lowest for cleaned
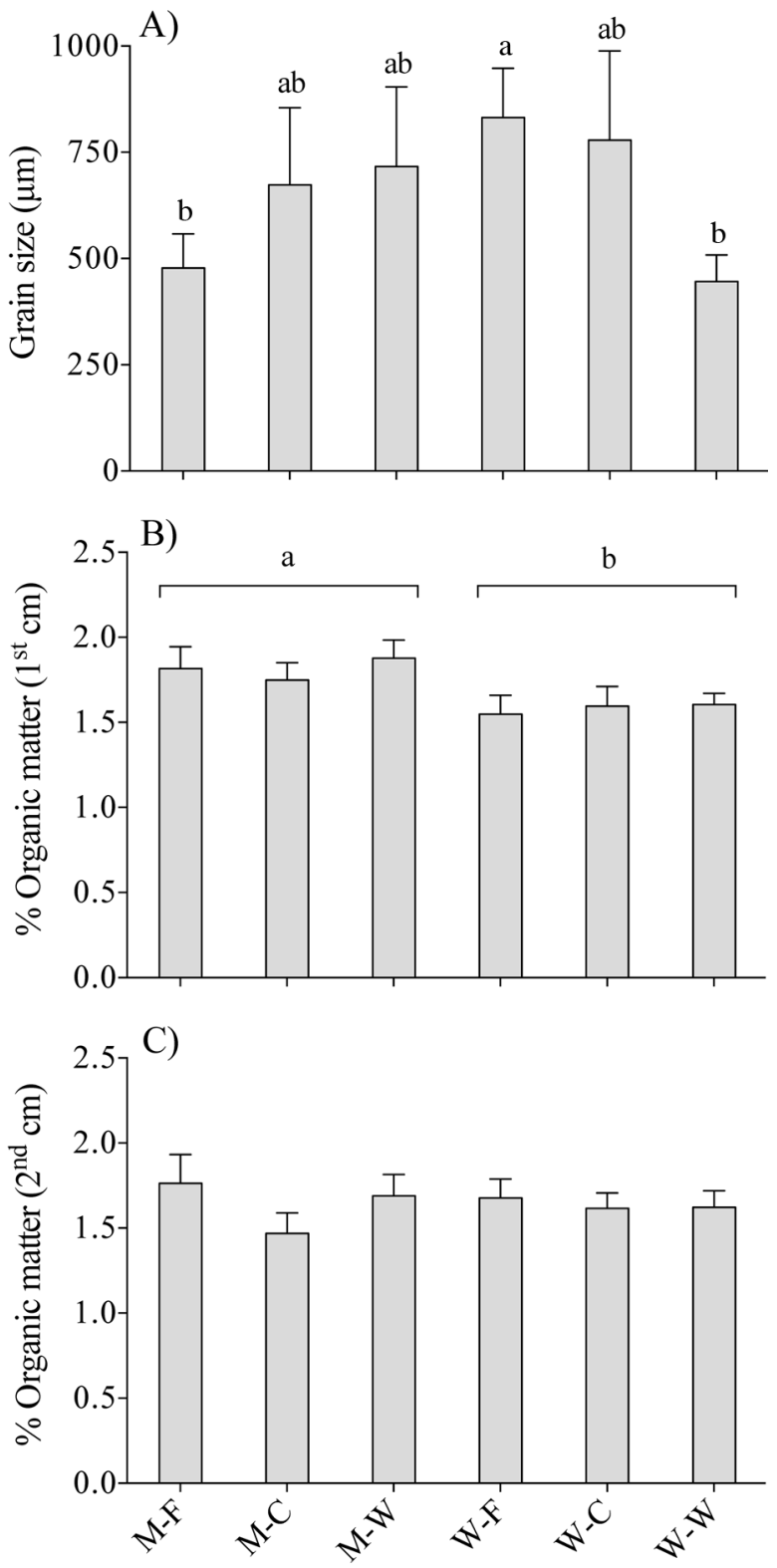

Treatments

Fig. 2. Mean (A) sediment grain size $( \pm \mathrm{SE}, \mathrm{n}=8)$ in the top $2 \mathrm{~cm}$ of the sediment and mean organic matter percentage in the (B) first (surficial) and (C) second centimetre of the sediment $( \pm \mathrm{SE}, \mathrm{n}=8)$. Treatments are combinations of presence (M) or absence (W) of Manila clams Venerupis philippinarum and anti-predator net status (F: fouled; $\mathrm{C}$ : cleaned; W: without). Different letters above bars indicate significant $(\mathrm{p}<0.05)$ differences between treatment levels based on a posteriori pair-wise comparisons

net treatments (Fig. 3, Table 2). SIMPER analysis showed that 6 taxa explained ca. $45 \%$ of the dissimilarity among the 3 net treatments: the bivalve Macoma sp., the polychaete Tharyx sp., the acorn barnacle Balanus crenatus, the Oregon shore crab 

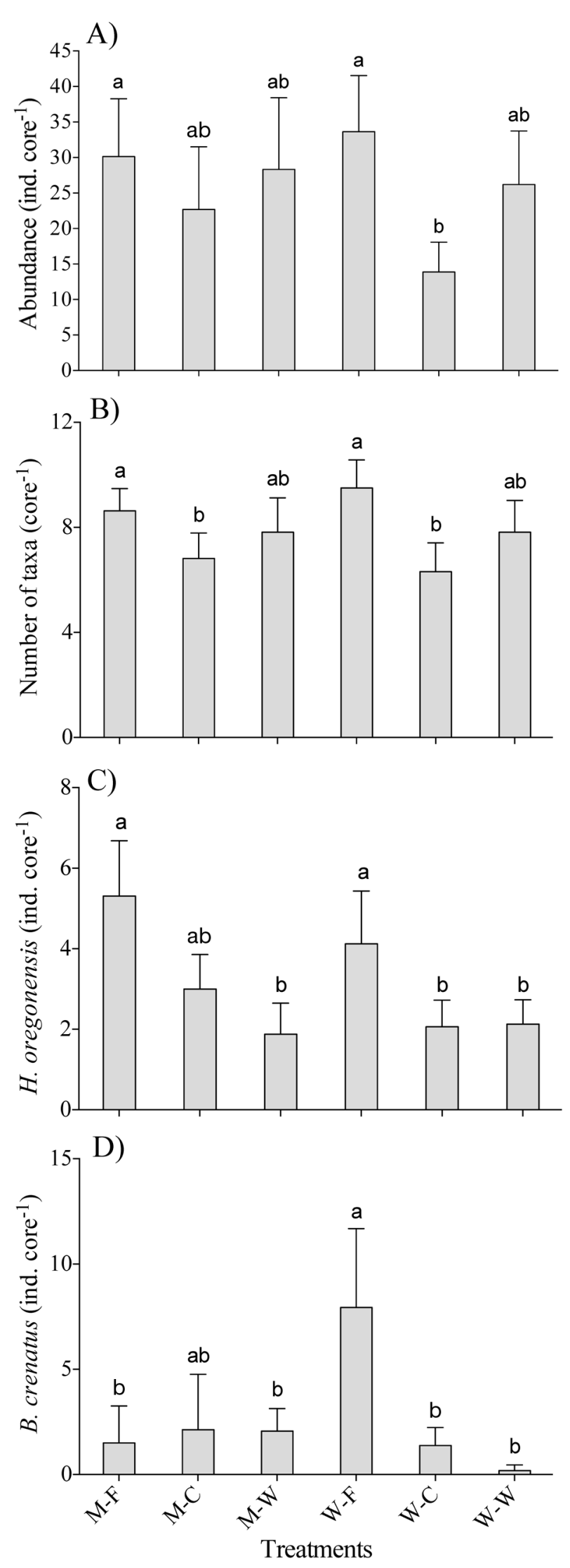

Table 2. Results of PERMANOVAs evaluating the effect of Clam (presence/absence), Net status (fouled, cleaned, or absent), and Plot (replicate plots for same treatment) on sediment macrofaunal community abundance and number of species (species richness). Significant effects $(p<0.05)$ are indicated in bold

\begin{tabular}{|c|c|c|c|c|}
\hline Source & df & MS & $F$ & $\mathrm{p}$ \\
\hline \multicolumn{5}{|l|}{ Abundance } \\
\hline Clam (C) & 1 & 549.29 & 0.983 & 0.3303 \\
\hline $\operatorname{Net}(\mathrm{N})$ & 2 & 1773.70 & 3.175 & 0.0465 \\
\hline $\mathrm{C} \times \mathrm{N}$ & 2 & 281.62 & 0.504 & 0.6239 \\
\hline $\operatorname{Plot}(\mathrm{C} \times \mathrm{N})$ & 42 & 558.74 & 7.926 & 0.0001 \\
\hline Error & 48 & 70.50 & & \\
\hline \multicolumn{5}{|l|}{ Richness } \\
\hline Clam (C) & 1 & 221.68 & 1.488 & 0.2254 \\
\hline $\operatorname{Net}(\mathrm{N})$ & 2 & 648.49 & 4.353 & 0.0170 \\
\hline $\mathrm{C} \times \mathrm{N}$ & 2 & 61.64 & 0.414 & 0.6791 \\
\hline $\operatorname{Plot}(\mathrm{C} \times \mathrm{N})$ & 42 & 148.96 & 2.891 & 0.0004 \\
\hline Error & 48 & 51.53 & & \\
\hline \multicolumn{5}{|c|}{ Hemigrapsus oregonensis } \\
\hline Clam (C) & 1 & 9.375 & 1.018 & 0.3190 \\
\hline Net $(\mathrm{N})$ & 2 & 66.448 & 7.218 & 0.0013 \\
\hline $\mathrm{C} \times \mathrm{N}$ & 2 & 4.719 & 0.513 & 0.5963 \\
\hline $\operatorname{Plot}(\mathrm{C} \times \mathrm{N})$ & 42 & 9.205 & 1.468 & 0.1042 \\
\hline Error & 48 & 6.271 & & \\
\hline \multicolumn{5}{|c|}{ Balanus crenatus } \\
\hline Clam (C) & 1 & 38.76 & 1.207 & 0.2870 \\
\hline $\operatorname{Net}(\mathrm{N})$ & 2 & 117.97 & 3.675 & 0.0268 \\
\hline $\mathrm{C} \times \mathrm{N}$ & 2 & 162.70 & 5.068 & 0.0074 \\
\hline $\operatorname{Plot}(\mathrm{C} \times \mathrm{N})$ & 42 & 32.10 & 0.869 & 0.6518 \\
\hline Error & 48 & 36.95 & & \\
\hline \multicolumn{5}{|c|}{ Community structure } \\
\hline Clam (C) & 1 & 18648.0 & 6.772 & 0.0001 \\
\hline $\operatorname{Net}(\mathrm{N})$ & 2 & 4126.2 & 1.498 & 0.1014 \\
\hline $\mathrm{C} \times \mathrm{N}$ & 2 & 4783.5 & 1.737 & 0.0475 \\
\hline $\operatorname{Plot}(\mathrm{C} \times \mathrm{N})$ & 42 & 2753.7 & 2.264 & 0.0001 \\
\hline Error & 48 & 1216.1 & & \\
\hline
\end{tabular}

Hemigrapsus oregonensis, the amphipod Grandidierella japonica, and the polychaete Pseudopolydora kempi. Of these taxa, 2 of the most abundant, $B$. crenatus and $H$. oregonensis, varied significantly among treatments (Fig. 3, Table 2). H. oregonensis abundance varied as a function of Net, the species being significantly more abundant when the nets were fouled. $B$. crenatus abundance varied as a

Fig. 3. Mean (A) abundance and (B) species richness (number of species) of macrofauna and abundance of (C) Hemigrapsus oregonensis and (D) Balanus crenatus $( \pm \mathrm{SE}, \mathrm{n}=16)$ from sediment. Treatments are combinations of presence (M) or absence (W) of Manila clams Venerupis philippinarum and anti-predator net status (F: fouled; $\mathrm{C}$ : cleaned; W: without). Different letters above bars indicate significant $(p<0.05)$ differences between treatment levels based on a posteriori pair-wise comparisons 
function of the Clam $\times$ Net interaction (Table 2) such that its density was fairly constant at about 2 plot $^{-1}$ in all treatments with clams, but varied from a high of 8 plot $^{-1}$ in the W-F treatment to close to 0 for the $\mathrm{W}-\mathrm{W}$ treatment. Multivariate community structure also varied as a function of the Clam $\times$ Net interaction (Table 2), but no clear trends were evident in the associated MDS plot (Fig. 4). With the elevated stress $(0.22)$, the projection in the figure is likely to represent only general relationships among data points.

\section{Macrofaunal communities: anti-predator nets}

The abundance of invertebrates on fouled nets was clearly greater than that on cleaned nets and did not vary as a function of the other factors (Fig. 5). To compare the abundance of all invertebrates among plot types, the data sets for organisms from sediment cores and netting were standardized per square metre and combined. This showed that the abundance of all macroinvertebrates in plots followed the same trends as the infaunal data (i.e. the greatest abundance in fouled net plots and the lowest in clean net plots), but this effect was accentuated by the inclusion of the net-related organisms. The biomass (mean $\pm \mathrm{SE}$ ) of macroalgae on fouled nets was $95 \pm$ 26.59 and $39 \pm 9.47 \mathrm{~g}$ for plots with and without Manila clams, respectively, but this difference was not statistically significant ( $t$-test, $\mathrm{p}=0.0689$ ).

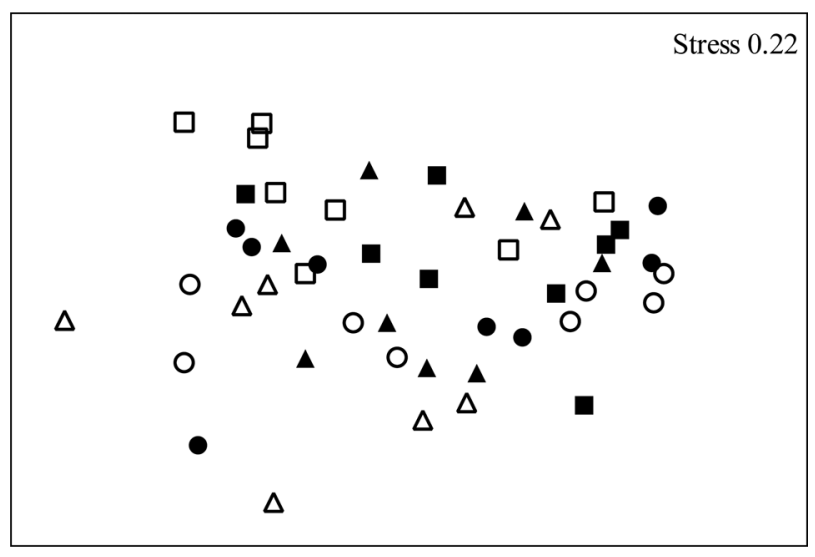

Fig. 4. Multi-dimensional scaling evaluating the effect of Manila clams and anti-predator netting status on benthic assemblage structure $(n=8)$. Treatments are combinations of presence (filled symbols) or absence (open symbols) of Manila clams Venerupis philippinarum and anti-predator net status (squares: fouled; triangles: cleaned; circles: without)

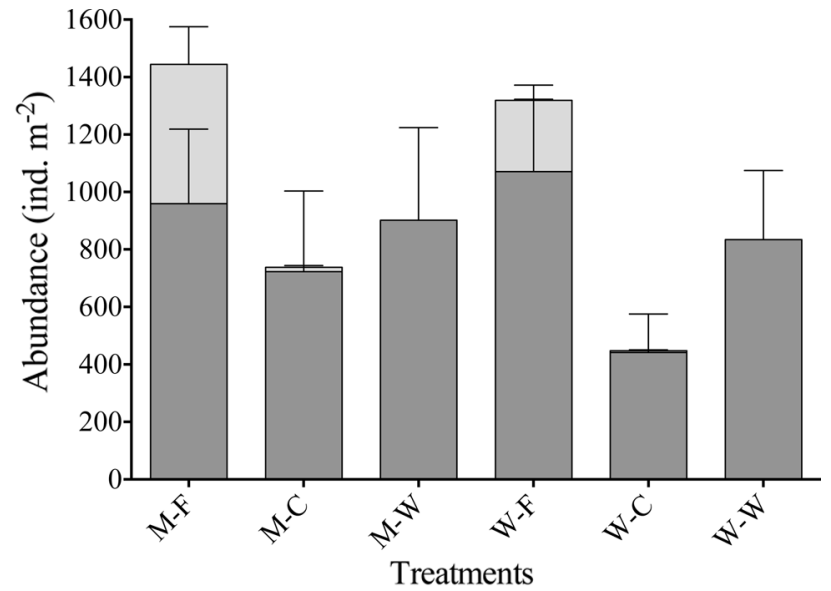

Fig. 5. Mean abundance $( \pm S E, n=8)$ of macrofauna present in sediments (dark grey) and on anti-predator nets (pale grey) from plots subjected to 1 of 6 treatments. Abundance is the number of individuals per square metre to have the unit consistent for sediment and nets. Treatments are combinations of presence (M) or absence (W) of Manila clams Venerupis philippinarum and anti-predator net status (F: fouled; C: cleaned; W: without)

\section{Biogeochemical fluxes}

Oxygen consumption and $\mathrm{NH}_{4}, \mathrm{PO}_{4}$, and $\mathrm{Si}(\mathrm{OH})_{4}$ fluxes across the water-sediment interface differed significantly with Clam treatment, oxygen consumption also varying significantly with Net treatment (Fig. 6, Table 3). Fluxes of all nutrients (except $\mathrm{NO}_{\mathrm{x}}$ ) were significantly greater in plots with Manila clams than in plots without them (Fig. 6). Oxygen consumption was greatest in treatments with fouled nets and least in treatments without nets (Fig. 6). Although mean $\mathrm{NO}_{\mathrm{X}}$ values were negative for the M-F treatment, representing a net uptake, and positive for all other treatments, this difference was not statistically significant (Fig. 6, Table 3).

\section{DISCUSSION}

Potential benthic effects of bivalve farming include sediment organic enrichment, impacts on benthic species and nutrient fluxes, and habitat alteration (e.g. Newell 2004, Dumbauld et al. 2009, Forrest et al. 2009, McKindsey et al. 2011). Infaunal clam aquaculture also impacts processes such as bioturbation and bioirrigation (Nizzoli et al. 2006a). The present study showed that Manila clam Venerupis philippinarum farming affects the benthic environment due to the farmed clams themselves, anti-predator nets, and fouling on these nets. 

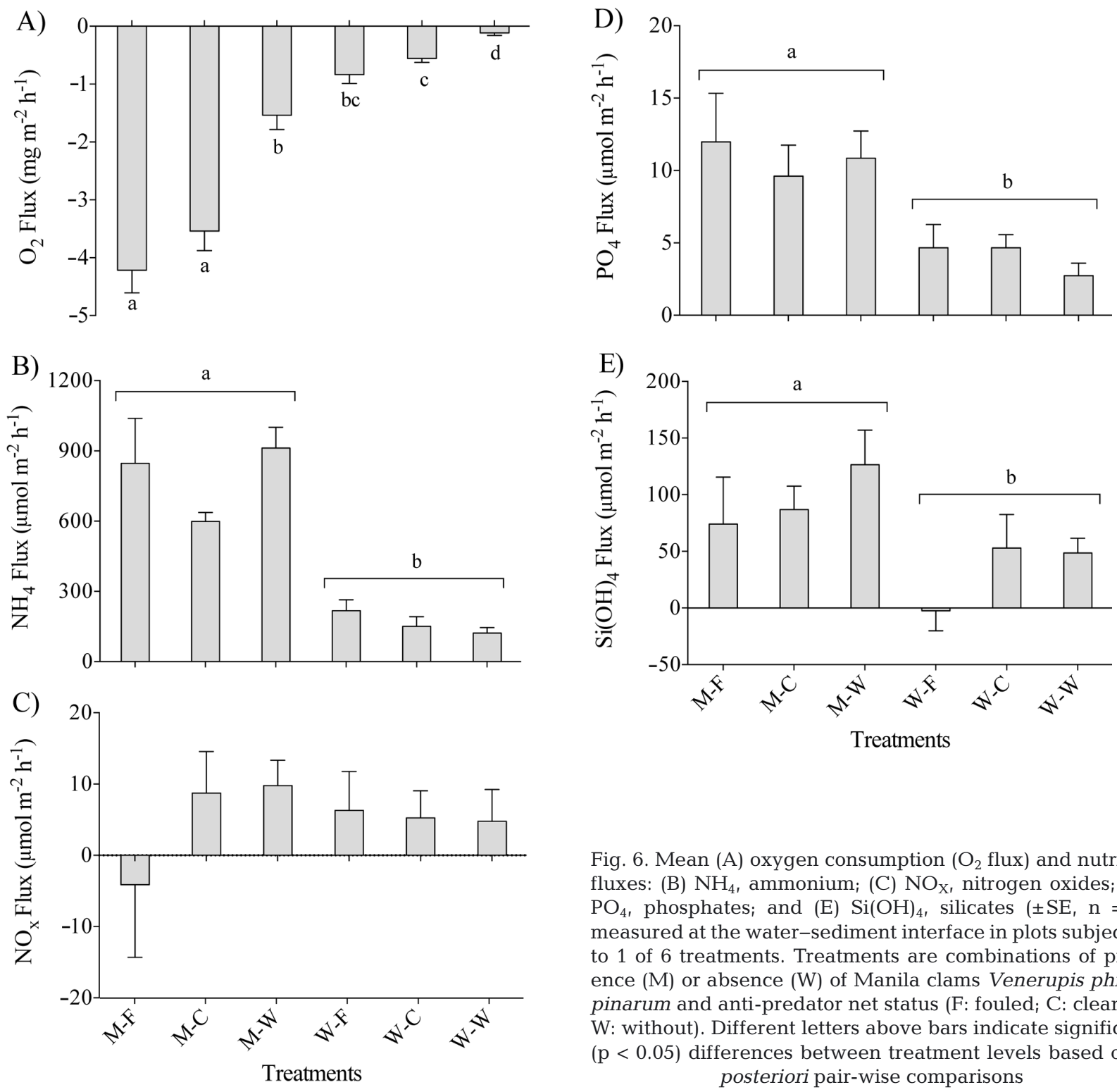

Fig. 6. Mean (A) oxygen consumption $\left(\mathrm{O}_{2}\right.$ flux $)$ and nutrient fluxes: (B) $\mathrm{NH}_{4}$, ammonium; (C) $\mathrm{NO}_{\mathrm{X}}$, nitrogen oxides; (D) $\mathrm{PO}_{4}$, phosphates; and (E) $\mathrm{Si}(\mathrm{OH})_{4}$, silicates $( \pm \mathrm{SE}, \mathrm{n}=8)$ measured at the water-sediment interface in plots subjected to 1 of 6 treatments. Treatments are combinations of presence (M) or absence (W) of Manila clams Venerupis philippinarum and anti-predator net status (F: fouled; C: cleaned; W: without). Different letters above bars indicate significant $(p<0.05)$ differences between treatment levels based on $a$ posteriori pair-wise comparisons

\section{Sediment characteristics}

Previous research has shown that anti-predator nets and fouling may obstruct or reduce water flow, increasing siltation (Kaiser et al. 1996, Spencer et al. 1996, 1997, Goulletquer et al. 1999, Munroe \& McKinley 2007, Nizzoli et al. 2007). In the present study grain size varied with net status, although this pattern differed between plots with and without clams. Manila clam biodeposits may be trapped by nets and incorporated as fine particles in sediments (Goulletquer et al. 1999), an effect that would likely be accentuated by net biofouling. However, processing with Calgon as a dispersant would cause biodeposits to break into smaller components, thus

explaining the observed trend in plots with Manila clams. The opposite pattern in plots without clams may result from size-specific arrival/retention of particles, with larger particles being retained by nets/fouling. In contrast, sediment structure did not differ between netted and non-netted treatments in the present study, as also reported by Munroe \& McKinley (2007) for Baynes Sound. This is in contrast to studies by Spencer et al. $(1996,1997)$ who observed a 4 -fold increase in sedimentation, but less silt, on netted plots compared to non-netted plots. This latter research was done over a complete 2 to 3 yr Manila clam cultivation cycle, unlike the present study. The short temporal scale and particular season over which the present study was done and the lim- 
Table 3. Results of 2-way ANOVAs evaluating the effect of Clam (presence/absence) and Net status (fouled, cleaned, or absent) on biogeochemical fluxes: $\mathrm{O}_{2}, \mathrm{NH}_{4}, \mathrm{NO}_{\mathrm{X}}, \mathrm{PO}_{4}$, and $\mathrm{Si}(\mathrm{OH})_{4}$. Significant effects $(\mathrm{p}<0.05)$ are indicated in bold

\begin{tabular}{|c|c|c|c|c|}
\hline Source & $\mathrm{df}$ & MS & $F$ & $\mathrm{p}$ \\
\hline \multicolumn{5}{|l|}{$\mathbf{O}_{2}$} \\
\hline Clam (C) & 1 & 12.993 & 238.804 & $<0.0001$ \\
\hline Net (N) & 2 & 1.976 & 36.315 & $<0.0001$ \\
\hline $\mathrm{C} \times \mathrm{N}$ & 2 & 0.123 & 2.268 & 0.1161 \\
\hline Error & 42 & 0.054 & & \\
\hline \multicolumn{5}{|l|}{$\mathrm{NH}_{4}$} \\
\hline Clam (C) & 1 & 2880.560 & 93.479 & $<0.0001$ \\
\hline Net (N) & 2 & 35.843 & 1.163 & 0.3224 \\
\hline $\mathrm{C} \times \mathrm{N}$ & 2 & 46.119 & 1.497 & 0.2356 \\
\hline Error & 42 & 30.815 & & \\
\hline \multicolumn{5}{|l|}{$\mathrm{NO}_{\mathbf{X}}$} \\
\hline Clam (C) & 1 & 0.542 & 0.050 & 0.8250 \\
\hline Net $(\mathrm{N})$ & 2 & 17.918 & 1.635 & 0.2070 \\
\hline $\mathrm{C} \times \mathrm{N}$ & 2 & 16.556 & 1.511 & 0.2324 \\
\hline Error & 42 & 10.956 & & \\
\hline \multicolumn{5}{|l|}{$\mathrm{PO}_{4}$} \\
\hline Clam (C) & 1 & 20.230 & 26.542 & $<0.0001$ \\
\hline Net $(\mathrm{N})$ & 2 & 1.111 & 1.457 & 0.2445 \\
\hline $\mathrm{C} \times \mathrm{N}$ & 2 & 0.599 & 0.786 & 0.4624 \\
\hline Error & 42 & 0.762 & & \\
\hline \multicolumn{5}{|l|}{$\mathrm{Si}(\mathrm{OH})_{4}$} \\
\hline Clam (C) & 1 & 47357.6 & 8.027 & 0.0071 \\
\hline Net $(\mathrm{N})$ & 2 & 11076.5 & 1.877 & 0.1656 \\
\hline $\mathrm{C} \times \mathrm{N}$ & 2 & 2478.9 & 0.420 & 0.6597 \\
\hline Error & 42 & 5900.1 & & \\
\hline
\end{tabular}

ited size $\left(2.25 \mathrm{~m}^{2}\right)$ of the experimental plots may explain why significant differences in sediment types were not observed.

In the present study, \%OM in the top centimetre of sediments was significantly greater in plots with Manila clams than in those without, but did not vary with net status, and significant treatment effects were not observed in deeper sediments. Likewise, Kanaya et al. (2005) found no effect of Manila clams on sediment organic carbon in Japan. Toupoint et al. (2008) also found a limited increase of organic content due to Manila clam culture, suggesting this may have been due to tidal currents or the short period that nets were used. Sediment organic content may be increased through clam biodeposition (Jie et al. 2001) or entrapment by anti-predator nets (Kaiser et al. 1996, Spencer et al. 1996, 1997, Bendell-Young 2006). Organic matter in biodeposits is easily degraded by microbial metabolism (Nizzoli et al. 2007), however, and thus may be rapidly assimilated. Clams may enhance oxygen transfer in the sediment through bioturbation, potentially speeding up organic matter decomposition (Kristensen 2000). Ultimately, the accumulation of organic matter in bivalve farms will depend on many variables, including species- and size-specific rates of biodeposit production, dispersal within the water column, redistribution on the sediment surface via resuspension, hydrodynamics, bed roughness, and decomposition rates (Giles et al. 2009).

\section{Macrofaunal communities}

The present study showed that Manila clams, per se, did not affect taxonomic abundance and richness but did affect multivariate community structure. The greatest effect on macrofaunal communities was due to anti-predator netting, as observed by Spencer et al. $(1996,1997)$. Several studies have reported that Manila clam farming does not impact multivariate community structure (Mantovani et al. 2006, Whiteley \& Bendell-Young 2007, Bendell 2014a). Likewise, Whiteley \& Bendell-Young (2007) found no difference in the abundance of a variety of clam species and clam taxonomic richness and abundance between British Columbia farm and reference sites. In contrast, in the same general geographical area, Bendell (2014a) observed the abundance of a number of individual taxa to differ between farm and reference sites, and Bendell (2014b) suggested that farming Manila clams may be leading to the decline of the native littleneck clam Leukoma staminea. Several studies conducted elsewhere have reported that macrofaunal abundance and taxonomic richness increase with Manila clam culture (Kaiser et al. 1996, Spencer et al. 1996, 1997), although Toupoint et al. (2008) observed the opposite effect.

Kaiser et al. (1996) predicted that species richness beneath nets in farmed areas would be greater than in control areas, pointing out that anti-predator netting reduces the effects of wave action and provides a more complex habitat structure. Spencer et al. (1996, 1997) observed a greater abundance of organisms under anti-predator nets than in reference areas but the same number of taxa. Anti-predator nets are installed to prevent predation on clams but also likely benefit other benthic infaunal organisms (Spencer et al. 1992). However, taxonomic abundance and richness of infauna were not greater in plots with nets relative to plots without nets in the present study, suggesting that nets, per se, do not create variation in benthic communities among Net treatments. Rather, it is more likely the net biofouling is affecting these communities.

Spencer et al. (1996) observed up to $100 \%$ cover of algae on Manila clam anti-predator nets, and Powers et al. (2007) have shown that epibiota may be 20 times 
more abundant on aquaculture netting than on adjacent sandflats, contributing to local diversity. Indeed, when epibiotic organisms on fouled nets are considered in the evaluation of taxonomic abundance, the total abundance of organisms in associated plots is seen to greatly increase, whereas that of plots with clean nets changes only slightly.

The 2 species that contributed most to the dissimilarity between net status were, on average, more abundant in plots with fouled nets. Oregon shore crabs Hemigrapsus oregonensis are very abundant under biofouled netting on the study beach (M.-F. Lavoie pers. obs.), an observation also made by Bendell (2014a). Thus, fouled anti-predator nets may offer protection and a suitable habitat for these small crabs on sandflat aquaculture areas where surficial structure is typically absent. These crabs are active predators of juvenile clams (Smith \& Langdon 1998), and Bendell (2014a) suggested that this may have numerous impacts on benthic communities, perhaps explaining why the predicted increase in infaunal abundance was not greater in treatments with nets. Although the barnacle Balanus crenatus is commonly found intertidally on rocks and other natural substrates (Cornwall 1955), it is also common on netting and other structures used in clam aquaculture. In the present study, B. crenatus was observed on antipredator nets and in infaunal sediment core samples, some of which likely included individuals that had fallen on the sediment when the nets were sampled.

\section{Biogeochemical fluxes}

Benthic respiration is a key measure of biological activity and the cycling of biologically important elements, including carbon, nitrogen, phosphorus, sulfur, and metals (Glud 2008). Oxygen levels may be impacted directly by the respiration of farmed bivalves (Bartoli et al. 2001, Nizzoli et al. 2007) and microbes that degrade clam biodeposits (Sorokin et al. 1999, Bartoli et al. 2001). In the present study, oxygen consumption for a given net status was about 5 to 15 times greater in treatments with clams than in those without them, an effect that was amplified by the presence of nets and net fouling. Nizzoli et al. (2007) observed that farmed Manila clams increased oxygen consumption 3.0 to 3.6 times that observed in a control site during the summer. Barnacles and macroalgae that grew on nets also likely increased oxygen consumption in fouled net treatments. In addition, bacterial communities associated with netting material may also contribute to respiration rates in plots with nets (Richard et al. 2007b). As incubations in the present study were conducted using opaque chambers, keeping them dark, algal photosynthesis would have been negligible and only their respiration would have contributed to oxygen fluxes. Patterns of oxygen fluxes would likely have differed had the benthic chambers permitted light penetration.

Nutrient regeneration from benthic sediments to the water column occurs through mineralization of organic material through aerobic and anaerobic processes (Glud 2008), both being stimulated by clam biodeposition (Kaspar et al. 1985, Baudinet et al. 1990, Bartoli et al. 2001, Nizzoli et al. 2007). Clam metabolic activity and bioirrigation due to clam movements may also release various nutrients (Bartoli et al. 2001, Welsh \& Castadelli 2004, Nizzoli et al. 2007, 2011). In addition, biofouling on anti-predator netting and associated microbial communities could have contributed to nutrient fluxes, as shown elsewhere (e.g. Richard et al. 2007b, Lacoste et al. 2014). This nutrient recycling may stimulate macroalgal productivity, especially in the summer when other nutrient sources may be limiting (Nizzoli et al. 2011), the algae potentially reducing nutrient fluxes to the water column by intercepting and assimilating them (Dalsgaard 2003).

Ammonium fluxes in the present study were about 5 times greater in treatments with clams than in treatments without them. Increased ammonium fluxes with Manila clam farming were also observed by Bartoli et al. (2001) and Nizzoli et al. (2011), the former observing that fluxes increased with clam density and the latter that ammonium fluxes in a farm were 4 to 15 times greater than those in a control area. Clams excrete large quantities of ammonium, which may represent about $90 \%$ of the total DIN (dissolved inorganic nitrogen: $\mathrm{NO}_{3}{ }^{-}+\mathrm{NO}_{2}{ }^{-}+\mathrm{NH}_{4}{ }^{+}$) release from sediments in treatments with Manila clams, as compared to only $30 \%$ of the total DIN release from sediments in treatments without the clams (Bartoli et al. 2001). Clam bioturbation and bioirrigation increase oxygen in sediments, thereby increasing the relative importance of nitrification and nitrate reduction processes (Nizzoli et al. 2006b). The concentration of ammonium in the water column, oxygen availability, and sediment organic matter content all influence nitrate balance (Kristensen 1988, Pina-Ochoa \& Alvarez-Cobelas 2006) and $\mathrm{NO}_{\mathrm{X}}$ dynamics (Nizzoli et al. 2011) in Manila clam farms. In well-oxygenated sediments, ammonium is reduced or re-oxidized to $\mathrm{NO}_{2}$ and $\mathrm{NO}_{3}$ (Purvaja et al. 2008). In the present study, the negative $\mathrm{NO}_{\mathrm{X}}$ flux observed in plots with clams and fouled nets may have been due to oxygen limitation such that denitri- 
fication was the dominant process (Pina-Ochoa \& Alvarez-Cobelas 2006). In contrast, nitrification was likely more important in the other treatments due to greater oxygenation of sediments.

Measured ammonium fluxes may represent only a fraction of the actual quantity of ammonium produced by Manila clams and other sources. Donadi et al. (2013) showed that high densities of infaunal bivalves may increase the biomass of microphytoplankton locally, and Komorita et al. (2010) showed that the bulk of ammonium released by Manila clams was consumed by microphytobenthos. Both benthic microphytoplankton (Clark et al. 2002) and macroalgae (Topinka \& Robbins 1976, Vandermeulen \& Gordin 1990) may assimilate ammonium under dark conditions, as in the experimental benthic chambers, and thus could have impacted measured fluxes.

Phosphate effluxes were greater in plots with clams than in those without them, as observed by Nizzoli et al. (2011). Following regeneration, phosphate may be fixed to iron ions in the sediment and not released at the water-sediment interface (Sundby et al. 1992). Thus, sediment phosphate efflux increases nonlinearly with clam density as benthic sediments adsorb phosphate (Nizzoli et al. 2006a). In addition, phosphate adsorption decreases with oxygen levels (Sundby et al. 1992), perhaps explaining why the greatest phosphate fluxes were observed in plots with clams or with fouled nets.

Silica fluxes were strongly stimulated by Manila clams, as observed by Bartoli et al. (2001). This has also been observed in sediments under mussel farms by Richard et al. (2007a) and Alonso-Pérez et al. (2010) and is thought to be due to degradation of silica-containing diatom frustules from bivalve biodeposits (Bartoli et al. 2001).

\section{Conclusion}

The present in situ manipulative experiment provides a better understanding of the relative effects of several factors related to Manila clam culture (i.e. clams, nets, biofouling on nets) that may impact sediment structure, benthic communities, and biogeochemical fluxes. Overall, the presence of Manila clams had greater impacts on sediment organic content and biogeochemical fluxes than did antipredator nets. The accumulation of organic matter in the top $1 \mathrm{~cm}$ was not impacted by netting but was by clams. Manila clams significantly affected several biogeochemical fluxes, increasing oxygen consumption and $\mathrm{NH}_{4}, \mathrm{PO}_{4}$, and $\mathrm{Si}(\mathrm{OH})_{4}$ regeneration. Anti- predator nets and net fouling increased oxygen consumption, abundance of organisms, and species richness. Results for oxygen differ from those for nutrients insomuch as the presence of clams, antipredator netting, and fouling on netting had additive effects on oxygen consumption. Fouled nets seem to provide refuge for shore crabs $H$. oregonensis, which may impact benthic communities. Although the great presence of ducks that target the farmed bivalves encourages the use of anti-predator nets in Baynes Sound, this work shows that cleaning or removing nets may limit effects on benthic community structure and oxygen demand.

Acknowledgements. We thank the funding agencies that supported the project: Canadian Healthy Oceans Network (CHONe), Fisheries and Oceans Canada (DFO), Natural Sciences and Engineering Research Council (NSERC), and Ressources Aquatiques Québec (RAQ). Various stages of this work were conducted at Laboratoire d'écologie benthique (UQAR/ISMER) and Institut Maurice-Lamontagne and the Pacific Biological Station (DFO). Mac's Oysters Ltd., facilitated by Rob Marshall, provided access to the site and some material support. Hud Mielty helped prepare the experimental site. We thank Annick Drouin, Émilie Lebrun, and Pauline Robert for all their help in the field. We also thank Sarah Dudas for input on experimental design and methodology, as well as Leah Bendell and Céline Audet for constructive comments on an earlier version of the manuscript.

\section{LITERATURE CITED}

Alonso-Pérez F, Ysebaert T, Castro CG (2010) Effects of suspended mussel culture on benthic-pelagic coupling in a coastal upwelling system (Ria de Vigo, NW Iberian Peninsula). J Exp Mar Biol Ecol 382:96-107

Anderson MJ, Gorley RN, Clarke KR (2008) PERMANOVA+ for PRIMER: guide to software and statistical methods. PRIMER-E, Plymouth

- Bartoli M, Nizzoli D, Viaroli P, Turolla E, Castaldelli G, Fano EA, Rossi R (2001) Impact of Tapes philippinarum farming on nutrient dynamics and benthic respiration in the Sacca di Goro. Hydrobiologia 455:203-212

Baudinet D, Alliot E, Berland B, Grenz C, Plante-Cuny MR, Plante R, Salen-Picard C (1990) Incidence of mussel culture on biogeochemical fluxes at the sediment-water interface. Hydrobiologia 207:187-196

BC Shellfish Grower's Association (2014) About the BCSGA. Industry encyclopedia. Clams. http://bcsga.ca/ (accessed 7 Feb 2014)

Bendell LI (2014a) Community composition of the intertidal in relation to the shellfish aquaculture industry in coastal British Columbia, Canada. Aquaculture 433:384-394

> Bendell LI (2014b) Evidence for declines in the native Leukoma staminea as a result of the intentional introduction of the non-native Venerupis philippinarum in coastal British Columbia, Canada. Estuaries Coasts 37: 369-380

Bendell LI, Wan PCY (2011) Application of aerial photography in combination with GIS for coastal management at 
small spatial scales: a case study of shellfish aquaculture. J Coast Conserv 15:417-431

Bendell-Young LI (2006) Contrasting the community structure and select geochemical characteristics of three intertidal regions in relation to shellfish farming. Environ Conserv 33:21-27

British Columbia Ministry of Sustainable Resource Management (2002) Baynes Sound coastal plan shellfish aquaculture. Resource Management Division, Victoria

Byers SC, Mills EL, Stewart PL (1978) A comparison of methods of determining organic carbon in marine sediments with suggestions for a standard method. Hydrobiologia 58:43-47

> Cabrita MT, Catarino F, Vale C (1999) The effect of tidal range on the flushing of ammonium from intertidal sediments of the Tagus estuary, Portugal. Oceanol Acta 22:291-302

> Callier MD, McKindsey CW, Desrosiers G (2008) Evaluation of indicators used to detect mussel farm influence on the benthos: two case studies in the Magdalen Islands, eastern Canada. Aquaculture 278:77-88

- Carswell B, Cheesman S, Anderson J (2006) The use of spatial analysis for environmental assessment of shellfish aquaculture in Baynes Sound, Vancouver Island, British Columbia, Canada. Aquaculture 253:408-411

Castaldelli G, Mantovani S, Welsh DT, Rossi R, Mistri M, Fano EA (2003) Impact of commercial clam harvesting on water column and sediment physicochemical characteristics and macrobenthic community structure in a lagoon (Sacca di Goro) of the Po River Delta. Chem Ecol 19: 161-171

> Clark DR, Flynn KJ, Owens NJP (2002) The large capacity for dark nitrate-assimilation in diatoms may overcome nitrate limitation of growth. New Phytol 155:101-108

Cornwall IE (1955) The barnacles of British Columbia. British Columbia Provincial Museum Handbook No. 7 , British Columbia Provincial Museum, Victoria

> Dalsgaard T (2003) Benthic primary production and nutrient cycling in sediments with benthic microalgae and transient accumulation of macroalgae. Limnol Oceanogr 48:2138-2150

> Doering PH, Kelly JR, Oviatt CA, Sowers T (1987) Effect of the hard clam Mercenaria mercenaria on benthic fluxes of inorganic nutrients and gases. Mar Biol 94:377-383

Donadi S, Westra J, Weerman E, van der Heide T and others (2013) Non-trophic interactions control benthic producers on intertidal flats. Ecosystems 16:1325-1335

Dumbauld BR, Ruesink JL, Rumrill SS (2009) The ecological role of bivalve shellfish aquaculture in the estuarine environment: a review with application to oyster and clam culture in West Coast (USA) estuaries. Aquaculture 290:196-223

FAO (Food and Agriculture Organization of the United Nations) (2014) The state of world fisheries and aquaculture, 2014. FAO Fisheries and Aquaculture Department, Rome

FAO Fisheries and Aquaculture Department (2013) Global datasets: total fishery production (FishStat Plus - Universal software for fishery statistical time series). www.fao. org/fishery/statistics/software/fishstat/en (accessed 10 Sep 2013)

Fisheries and Oceans Canada (2013) Aquaculture statistics, facts and figures. www.dfo-mpo.gc.ca/aquaculture/ stats/index-eng.htm (accessed 6 Feb 2014)

Forrest BM, Keeley NB, Hopkins GA, Webb SC, Clement DM (2009) Bivalve aquaculture in estuaries: review and synthesis of oyster cultivation effects. Aquaculture 298:
$1-15$

Giles H, Broekhuizen N, Bryan KR, Pilditch CA (2009) Modelling the dispersal of biodeposits from mussel farms: the importance of stimulating biodeposit erosion and decay. Aquaculture 291:168-178

- Glud RN (2008) Oxygen dynamics of marine sediments. Mar Biol Res 4:243-289

Goulletquer P, Robert R, Trut G (1999) Manila clams Tapes philippinarum culture: sediment-clam interactions. Aquat Living Resour 12:45-56

Guyondet T, Sonier R, Comeau LA (2013) Spatially explicit seston depletion index to optimize shellfish culture. Aquacult Environ Interact 4:175-186

Holmes RM, Aminot A, Kerouel R, Hooker BA, Peterson BJ (1999) A simple and precise method for measuring ammonium in marine and freshwater ecosystems. Can J Fish Aquat Sci 56:1801-1808

Jamieson GS, Chew L, Gillespie G, Robinson A and others (2001) Phase 0 review of the environmental impacts of intertidal shellfish aquaculture in Baynes Sound. Fisheries and Oceans Science, Canadian Science Advisory Secretariat Research, Ottawa

Jie H, Zhinan Z, Zishan Y, Widdows J (2001) Differences in the benthic-pelagic particle flux (biodeposition and sediment erosion) at intertidal sites with and without clam (Ruditapes philippinarum) cultivation in eastern China. J Exp Mar Biol Ecol 261:245-261

Kaiser MJ, Edwards DB, Spencer BE (1996) Infaunal community changes as a result of commercial clam cultivation and harvesting. Aquat Living Resour 9:57-63

> Kanaya G, Nobota E, Toya T, Kikuchi E (2005) Effects of different feeding habits of three bivalve species on sediment characteristics and benthic diatom abundance. Mar Ecol Prog Ser 299:67-78

Kaspar HF, Gillespie PA, Boyer IC, Mackenzie AL (1985) Effects of mussel aquaculture on the nitrogen cycle and benthic communities in Kenepuru Sound, Marlborough Sounds, New Zealand. Mar Biol 85:127-136

Komorita T, Kajihara R, Tsutsumi H, Shibanuma S, Yamada T, Higaki N, Montani S (2010) Reevaluation of the nutrient mineralization process by infaunal bivalves (Ruditapes philippinarum) in a shallow lagoon in Hokkaido, Japan. J Exp Mar Biol Ecol 383:8-16

Kristensen E (1988) Benthic fauna and biogeochemical processes in marine sediments: microbial activities and fluxes. In: Blackburn TH, Sorensen J (eds) Nitrogen cycling in coastal marine environments. John Wiley \& Sons Ltd, Chichester, p 275-299

- Kristensen E (2000) Organic matter diagenesis at the oxic/anoxic interface in coastal marine sediments, with emphasis on the role of burrowing animals. Hydrobiologia 426:1-24

Lacoste E, Gueguen Y, Le Moullac G, Koua MS, GaertnerMazouni N (2014) Influence of farmed pearl oysters and associated biofouling communities on nutrient regeneration in lagoons of French Polynesia. Aquacult Environ Interact 5:209-219

Lewis TL, Esler D, Boyd WS (2007) Effects of predation by sea ducks on clam abundance in soft-bottom intertidal habitats. Mar Ecol Prog Ser 329:131-144

> Magni P, Montani S, Takada C, Tsutsumi H (2000) Temporal scaling and relevance of bivalve nutrient excretion on a tidal flat of the Seto Inland Sea, Japan. Mar Ecol Prog Ser 198:139-155

> Mantovani S, Castaldelli G, Rossi R, Fano EA (2006) The infaunal community in experimentally seeded low and high density Manila clam (Tapes philippinarum) beds in 
a Po River Delta lagoon (Italy). ICES J Mar Sci 63: 860-866

Mattsson J, Lindén O (1983) Benthic macrofauna succession under mussels, Mytilus edulis L. (Bivalvia), cultured on hanging long-lines. Sarsia 68:97-102

Mazouni N, Deslous-Paoli JM, Landrein S (1998) Influence d'un élevage ostréicole sur les flux de nutriments et d'oxygène dans un écosystème lagunaire. Oceanol Acta 21:845-857

McCave IN, Bryant RJ, Cook HF, Couchanowr CA (1986) Evaluation of a laser-diffraction-size analyzer for use with natural sediments. J Sediment Petrol 56:561-564

McKindsey CW, Archambault P, Callier MD, Olivier F (2011) Influence of suspended and off-bottom mussel culture on the sea bottom and benthic habitats: a review. Can J Zool 89:622-646

Munroe D, McKinley RS (2007) Commercial Manila clam (Tapes philippinarum) culture in British Columbia, Canada: the effects of predator netting on intertidal sediment characteristics. Estuar Coast Shelf Sci 72:319-328

Navarro JM, Thompson RJ (1997) Biodeposition by the horse mussel Modiolus modiolus (Dillwyn) during the spring diatom bloom. J Exp Mar Biol Ecol 209:1-13

- Naylor RL, Goldburg RJ, Primavera JH, Kautsky N and others (2000) Effect of aquaculture on world fish supplies. Nature 405:1017-1024

Newell RIE (2004) Ecosystem influences of natural and cultivated populations of suspension-feeding bivalve molluscs: a review. J Shellfish Res 23:51-61

> Nizzoli D, Bartoli M, Viaroli P (2006a) Nitrogen and phosphorous budgets during a farming cycle of the Manila clam Ruditapes philippinarum: an in situ experiment. Aquaculture 261:98-108

> Nizzoli D, Welsh DT, Fano EA, Viaroli P (2006b) Impact of clam and mussel farming on benthic metabolism and nitrogen cycling, with emphasis on nitrate reduction pathways. Mar Ecol Prog Ser 315:151-165

Nizzoli D, Bartoli M, Viaroli P (2007) Oxygen and ammonium dynamics during a farming cycle of the bivalve Tapes philippinarum. Hydrobiologia 587:25-36

Nizzoli D, Welsh DT, Viaroli P (2011) Seasonal nitrogen and phosphorus dynamics during benthic clam and suspended mussel cultivation. Mar Pollut Bull 62: 1276-1287

Pina-Ochoa E, Alvarez-Cobelas M (2006) Denitrification in aquatic environments: a cross-system analysis. Biogeochemistry 81:111-130

Powers MJ, Peterson CH, Summerson HC, Powers SP (2007) Macroalgal growth on bivalve aquaculture netting enhances nursery habitat for mobile invertebrates and juvenile fishes. Mar Ecol Prog Ser 339:109-122

Purvaja R, Ramesh R, Ray AK, Rixen T (2008) Nitrogen cycling: a review of processes, transformations and fluxes in coastal ecosystems. Curr Sci India 94:1419-1438

Quinn GP, Keough MJ (2002) Experimental design and data analysis for biologists. Cambridge University Press, Cambridge

Richard M, Archambault P, Thouzeau G, Desrosiers G (2006) Influence of suspended mussel lines on the biogeochemical fluxes in adjacent water in the Îles-de-laMadeleine (Quebec, Canada). Can J Fish Aquat Sci 63: 1198-1213

Richard M, Archambault P, Thouzeau G, Desrosiers G (2007a) Summer influence of 1 and 2 yr old mussel cultures on benthic fluxes in Grande-Entrée lagoon, Îles-
de-la-Madeleine (Québec, Canada). Mar Ecol Prog Ser 338:131-143

Richard M, Archambault P, Thouzeau G, McKindsey CW, Desrosiers G (2007b) Influence of suspended scallop cages and mussel lines on pelagic and benthic biogeochemical fluxes in Havre-aux-Maisons Lagoon, îles-dela-Madeleine (Quebec, Canada). Can J Fish Aquat Sci 64:1491-1505

> Robert P, McKindsey CW, Chaillou G, Archambault P (2013) Dose-dependent response of a benthic system to biodeposition from suspended blue mussel (Mytilus edulis) culture. Mar Pollut Bull 66:92-104

> Ross KA, Thorpe JP, Brand AR (2004) Biological control of fouling in suspended scallop cultivation. Aquaculture 229:99-116

Schumacher BA (2002) Methods for the determination of total organic carbon (TOC) in soils and sediments. United States Environmental Protection Agency, Ecological Risk Assessment Support Center, Las Vegas, NV

Smith MD, Langdon CJ (1998) Manila clam aquaculture on shrimp-infested mudflats. J Shellfish Res 17:223-229

Sorokin II, Giovanardi O, Pranovi F, Sorokin PI (1999) Need for restricting bivalve culture in the southern basin of the Lagoon of Venice. Hydrobiologia 400:141-148

> Spencer BE, Edwards DB, Millican PF (1992) Protecting Manila clam (Tapes philippinarum) beds with plastic netting. Aquaculture 105:251-268

Spencer BE, Kaiser MJ, Edwards DB (1996) The effect of Manila clam cultivation on an intertidal benthic community: the early cultivation phase. Aquacult Res 27:261-276

Spencer BE, Kaiser MJ, Edwards DB (1997) Ecological effects of intertidal Manila clam cultivation: observations at the end of the cultivation phase. J Appl Ecol 34: $444-452$

Sundby B, Gobeil C, Silverberg N, Mucci A (1992) The phosphorus cycle in coastal marine sediments. Limnol Oceanogr 37:1129-1145

Thouzeau G, Grall J, Clavier J, Chauvaud L and others (2007) Spatial and temporal variability of benthic biogeochemical fluxes associated with macrophytic and macrofaunal distributions in the Thau lagoon (France). Estuar Coast Shelf Sci 72:432-446

> Topinka JA, Robbins JV (1976) Effects of nitrate and ammonium enrichment on growth and nitrogen physiology in Fucus spiralis. Limnol Oceanogr 21:659-664

Toupoint N, Godet L, Fournier J, Retière C, Olivier F (2008) Does Manila clam cultivation affect habitats of the engineer species Lanice conchilega (Pallas, 1766)? Mar Pollut Bull 56:1429-1438

> Vandermeulen H, Gordin H (1990) Ammonium uptake using Ulva (Chlorophyta) in intensive fishpond systems: mass culture and treatment of effluent. J Appl Phycol 2: 363-374

- Weise AM, Cromey CJ, Callier MD, Archambault P, Chamberlain J, McKindsey CW (2009) Shellfish-DEPOMOD: modelling the biodeposition from suspended shellfish aquaculture and assessing benthic effects. Aquaculture 288:239-253

Welsh DT, Castadelli G (2004) Bacteria nitrification activity directly associated with isolated benthic marine animals. Mar Biol 144:1029-1037

Whiteley J, Bendell-Young L (2007) Ecological implications of intertidal mariculture: observed differences in bivalve community structure between farm and reference sites. J Anim Ecol 44:495-505 